\title{
ArcheoSciences
}

Revue d'archéométrie

\section{The earliest gold objects in Italy: a review of the archaeological evidence}

Les plus anciens objets d'or découverts en Italie : bilan des données

archéologiques

\section{Giovanna Bergonzi}

\section{OpenEdition}

Journals

Édition électronique

URL : http://journals.openedition.org/archeosciences/2066

DOI : 10.4000/archeosciences.2066

ISBN : 978-2-7535-1598-7

ISSN : 2104-3728

Éditeur

Presses universitaires de Rennes

\section{Édition imprimée}

Date de publication : 31 décembre 2009

Pagination : $91-97$

ISBN : 978-2-7535-1181-1

ISSN : $1960-1360$

\section{Référence électronique}

Giovanna Bergonzi, «The earliest gold objects in Italy: a review of the archaeological evidence », ArcheoSciences [En ligne], 33 | 2009, mis en ligne le 10 décembre 2012, consulté le 05 février 2021. URL : http://journals.openedition.org/archeosciences/2066 ; DOI : https://doi.org/10.4000/ archeosciences.2066 


\title{
The earliest gold objects in Italy: a review of the archaeological evidence
}

\section{Les plus anciens objets d'or découverts en Italie : bilan des données archéologiques}

\author{
Giovanna BergonzI*
}

\begin{abstract}
This paper aims to provide updated information on prehistoric gold from Italy, originating from pre-Iron Age contexts. The evidence dating from the beginning of the Metal Age is scanty indeed: to date, only 4 objects appear to be from an earlier period than the Middle Bronze Age. More gold finds were discovered from the MBA onwards, in part from funerary contexts, representing property or funerary gifts pertaining to individuals of both sexes who attained a high status within the community.
\end{abstract}

Résumé : Le but de ce travail est de fournir des informations mises à jour sur les objets d'or préhistoriques découverts en Italie et datant des périodes précédent l'Âge du Fer. Les objets datant du début de l'Âge des Métaux sont très peu nombreux : jusqu'à présent seulement quatre objets semblent dater d'avant l'Âge du Bronze moyen. A partir de cette période, les objets d'or, parfois trouvés en contexte funéraire sous forme de parure ou d'offrande, deviennent plus nombreux. Ces parures ou offrandes accompagnent seulement quelques individus, hommes ou femmes, dont le niveau social était élevé.

Keywords: Italy, prehistoric, gold.

Mots-clés : Italie, préhistorique, or.

\section{INTRODUCTION}

Gold is scarce in prehistoric contexts from Italy: objects are very few, and the quantity of metal very small. That is very likely one of the reasons why Italy was not included in the SAM gold project (Hartmann, 1970; 1982), while it had been included in a previous project concerning copper / bronze finds (Junghans et al., 1960; 1968). A review of the earliest gold finds from central Italy was published at the time by an archaeologist (von Hase, 1975). Later on, Bronze Age gold objects were neither included in projects on Bronze Age metalwork (Artioli et al., 2005), nor in studies concerning ancient gold from Italy, which were focused on later and more attractive finds (e.g. Cristofani and Martelli, 1983).

In 1995, M. Primas put on a map of Europe the gold and silver objects dated earlier than $2600 \mathrm{BC}$ and observed that, while in some areas silver was more ancient, in others it was gold (Primas, 1995; 1996). In Italy, silver metallurgy is the more ancient one: until today, several ancient small silver finds were identified on the coasts of the Tyrrhenian Sea and in Sardinia (Bergonzi forthcoming), while early gold objects are very limited in number and dating to a later period, very likely not earlier than the second half of the third or the beginning of the second millennium BC. 
This review article aims to provide a synthetic but comprehensive description of the prehistoric gold finds and of the archaeological contexts they originate from, as well as to investigate how they changed over time.

\section{MethodS}

In order to understand the role played by gold objects for Bronze Age society, the various types of objects are briefly discussed and archaeological contexts are taken into consideration as well. These data and the geographical provenance are sketchily summarised in Figures 1-3.

\section{RESUltS AND DisCUSSION}

During the period between the Copper Age (hereafter CA) and the Early Bronze Age (hereafter EBA), approximately
3500-1700 BC, gold finds are scanty indeed (List 1, Fig. 1). In Sardinia, a small electrum torc with open ends was discovered in a CA/EBA megalithic grave at Bingia 'e Monti, Gonnostramatza, containing multiple burials and, among other grave goods, also several bell beakers (List 1, n. 3). In Northern Italy, two small gold wire spiral rings were found in an EBA fossa grave cemetery near Verona, at Gazzo Veronese, under the skulls of two skeletons; they were also part of a headdress (List 1, n. 2). The fossa tombs appear to contain either poor or no grave goods at all, but might have also been looted, a frequent practice in contemporary Austrian cemeteries where similar gold finds were common (NeugebauerMaresch and Neugebauer, 1988/89). In the lake dwellings at Lavagnone a curved gold wire, $3 \mathrm{~cm}$ long, with one end found broken, was identified in a late EBA stratigraphic unit; it "might have been part of a double spiral pendant" (List 1, n. 1). In the south of Italy, a tiny blue glass bead with gold foil from a settlement at Mursia on Pantelleria Island probably belongs to the first half of the second millennium $\mathrm{BC}$

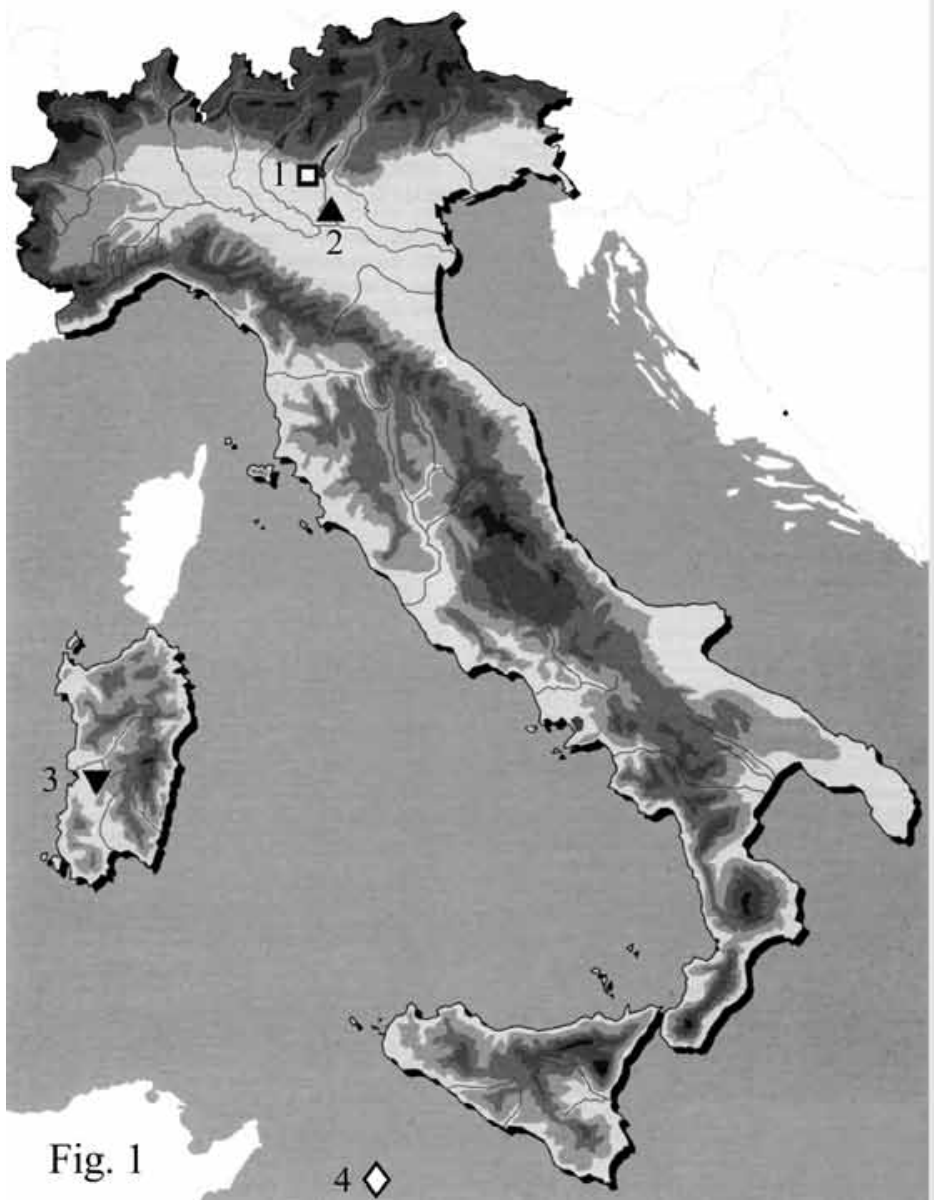

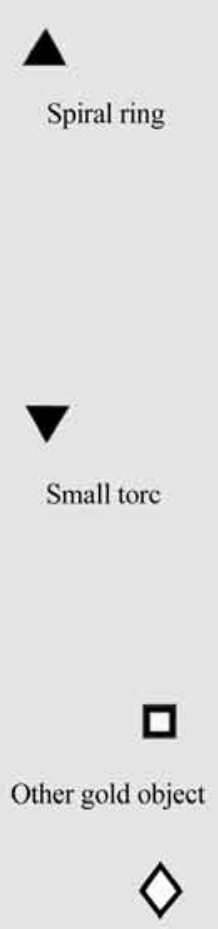
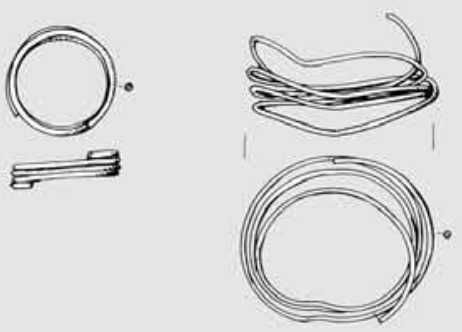

A glass bead with gold foil

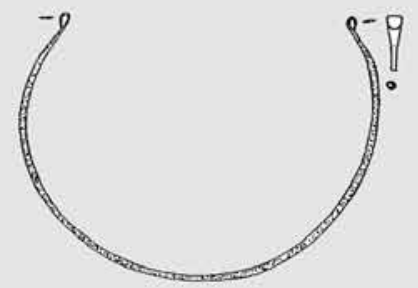

1. Desenzano del Garda, Lavagnone (Brescia)

2. Gazzo Veronese, Corte Valserà (Verona)

3. Gonnostramatza, Bingia e' Monti (Oristano)

4. Pantelleria, Mursia (Trapani)

Figure 1: Gold finds before the Middle Bronze Age. Full symbols: objects from tombs.

Figure 1 : Trouvailles datant d'avant l'Âge du Bronze moyen. Symboles pleins : objets provenant de tombes. 
(List 1, n. 4). These small objects - a torc, two hair spirals, a possible pendant, one bead - are adornments mostly worn on the head or around the neck by high status individuals, and might have been imports; they do not appear to be in the vicinity of mineral deposits (e.g. Piana Agostinetti et al., 1995; Lehrberger, 1995).

During the time span between the Middle Bronze Age (hereafter MBA) and the early phase of the Late Bronze Age (hereafter LBA), approximately 1700-1200 BC, the findings of gold objects increase in number (List 2, Fig. 2). Such objects are found mainly in two areas, northern Italy, in and around the Po plain, where gold objects originate primarily from settlements, and eastern Sicily, where gold finds came to light in chamber tomb cemeteries and are in part regarded as likely imports from the Aegean, while those in northern Italy might come from the north, possibly from the Alps. The most frequent gold objects are rings, and spiral rings are especially common in the Italian peninsula; the largest spiral rings (List 2, n. 4) are regarded as a pair of arm rings. Quite a few of these artefacts are finger rings, like those from Sicily, plain bands, or rings with a middle expansion imitating a signet ring. In Sicily, gold foil pendants and beads, which may have been imports, were discovered, as well as local daggers with a small gold rivet in the hilt. All these objects were very likely worn by individuals who belonged to the dominating elite, not only on the head or around the neck, but also on the hands (finger rings), or on symbols of power, like the daggers (rivets).

Quite different was the function of the gold foil discs, which were not pendants but had to be affixed on a support. They very likely were solar symbols used in ceremonies, possibly religious ones, and they were compared to the well known Trundholm chariot (e.g. Bettelli, 1997).

During the late phase of the Late Bronze Age (the socalled 'Bronzo finale' or Final Bronze Age), approximately 1200-950 BC, while there were still several finds in north-
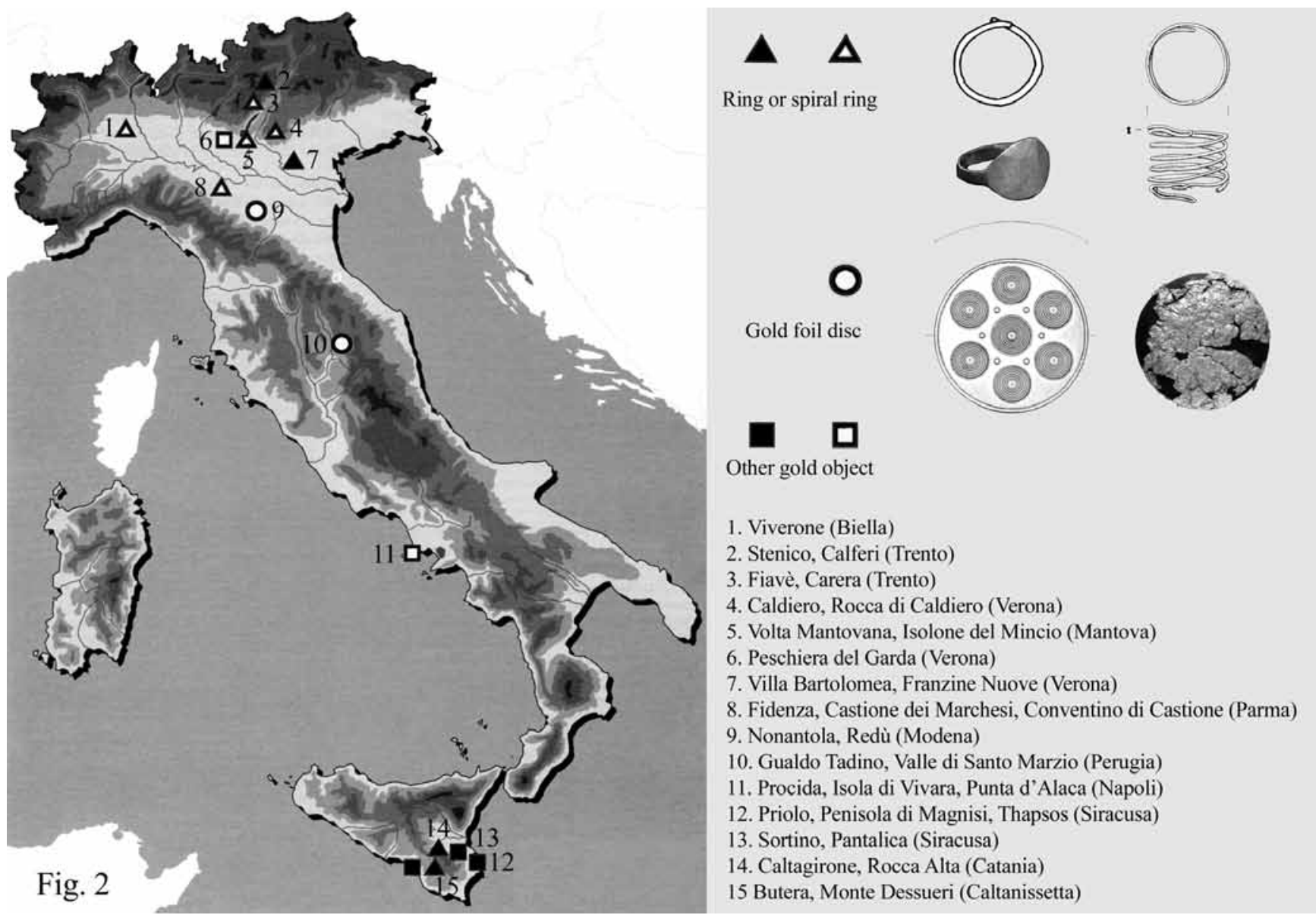

Figure 2: Gold finds from the Middle Bronze Age and early phase of Late Bronze Age. Full symbols: objects from tombs. Figure 2: Trouvailles datant de l'Âge du Bronze moyen et de la première phase de l'Age du Bronze final. Symboles pleins : objets provenant de tombes. 
ern Italy and in eastern Sicily, by this time gold objects had become more widespread: such artefacts were also found in central and southern Italy, and in Sardinia (List 3. Fig. 3). Most of them were found in tombs rather than settlements. To a great extent, they still represent the same typologies: rings and spiral rings are the most frequent ones, followed by gold rivets in the hilts of swords or daggers, and gold foil objects, among which the repoussé decorated gold foil discs are the most remarkable.

During this time span, the link with the dominating elite appears to be especially evident. Tiny quantities of gold could be worn both by males, such as the warrior from the Frattesina Le Narde tomb 227 (List 3, n. 4A), who, alone among over 500 burials, had a gold ring, gold rivets in the sword hilt and buttons with gold inlays, and by females, such as the lady from the Morano tomb 12 (List 3, n. 1), who, among several other objects, had a tiny open ended gold ring, which according to the excavators might have been an earring.

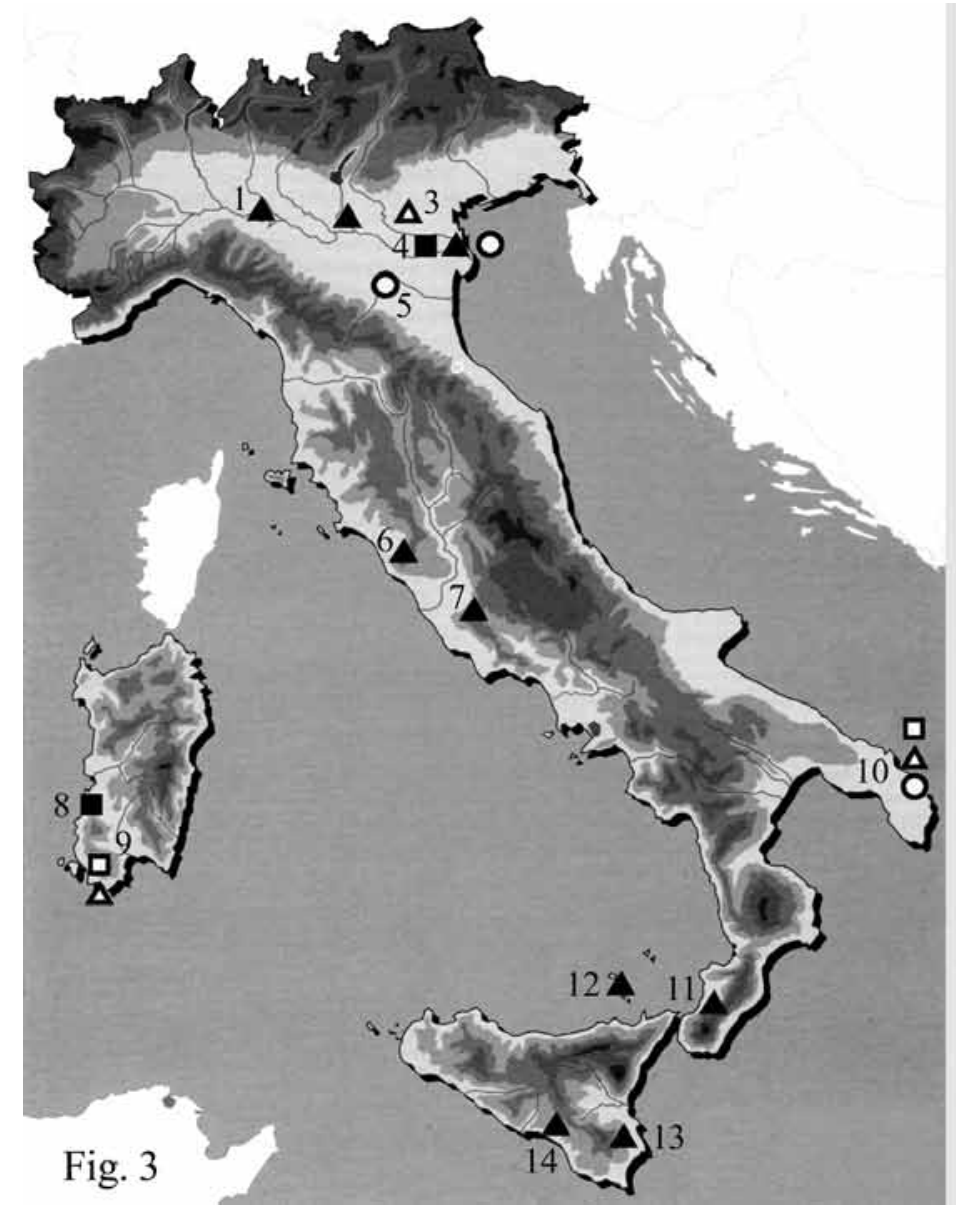

Several gold objects were found in two extraordinary settlements on the Adriatic coast, which were very likely 'emporia': Frattesina (List 3, n. 4) in the north and Roca Vecchia (List 3, n. 8) in the south. In Frattesina, in addition to the already mentioned objects from the Le Narde tomb 227, a gold foil disc and several gold foil fragments were found in the settlement area. Yet more spectacular are the finds from Roca Vecchia: at least four gold foil discs, forming at least two pairs, three spiral rings, and one gold foil bead were found on the floor and in a small hole under the floor of a large building (approximately $40 \times 15 \mathrm{~m}$ ), which the excavators interpreted as a 'hut- temple'.

In any case, when considered in its entirety, this most spectacular of all Italian finds weighed little more than $46 \mathrm{~g}$. Metal quantities are also very small: the CA/EBA Sardinian torc (List 1, n. 3) weights less than $12 \mathrm{~g}$; an MBA spiral ring from Fiavè (List 2, n. 3) only 1 g. Nevertheless, the symbolic value of gold is evident: it is linked to high status individuals, but also, during the LBA, to ceremonies, possibly reli-

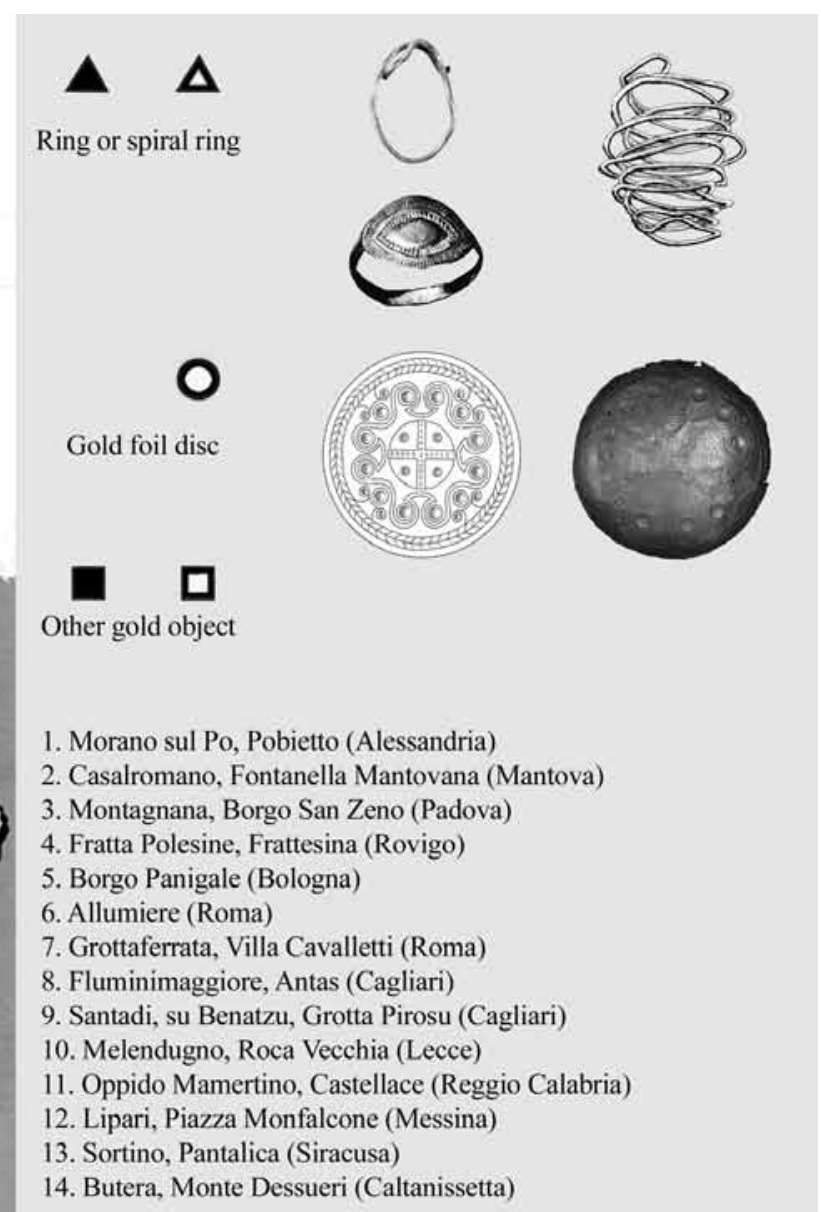

Figure 3: Gold finds from the late phase of Late Bronze Age. Full symbols: objects from tombs.

Figure 3 : Trouvailles datant de la fin de l'Âge du Bronze final. Symboles pleins : objets provenant de tombes. 
gious ones, and to 'emporia' which had intensive exchanges with the Aegean area, such as Frattesina and Roca Vecchia.

\section{ReFERENCES FOR Figures 1-3}

List 1, Figure 1: LCA - EBA: 1) de Marinis, 2000: 116, tav. XIX, b. 2) Salzani, 1998/1999: figs. 3; 4; 7, 6; 8, 1. 3) Atzeni E. 1998: 258, figs. 8, 3; p. 314, n. 143, fig. 31; Atzeni C. et al., 2003: 103-104. 4) Giardino and Merkouri, 2008: 118 .

List 2, Figure 2: MBA to early LBA: 1) Bertone et al. 2004: 67, fig. 37. 2) Perini, 1987: 36, fig. 15b. 3) Perini, 1987: 36, fig. 15a. 4) Caldiero, Rocca di Caldiero (Verona): Aspes and Salzani, 1997: 538, fig. 1; 540; 552, nr. 28-29. 5) Guerreschi et al., 1985: 87, tab. XXIII. 6) Peschiera: A violin bow bronze fibula plated with gold foil: von Hase 1975: 101, n. 57, fig. 4. 7) Aspes, 1987. 8) Mutti et al., 1988: 161. 9) Bermond Montanari, 1990: 72; Bettelli, 1997: 733, fig. 732a, b. 10) Peroni, 1963; Bietti Sestieri, 1973; Bettelli, 1997: 734-735. 11).Giardino, 1998: 160, fig. 6; Marazzi, 1999, 420, fig. 7. 12) Voza, 1973; Voza, 1997: 174. 13A) Orsi, 1899: coll. 46-47, tab. VII, 17; Peroni, 1956: fig. 3; Procelli et al., 2004: figs. 2, 7. 13B) Orsi, 1899: coll. 55-56, tab. VIII, 9. 13. 16; Peroni, 1956: fig. 6; Procelli et al., 2004: fig. 2, 2-6. 14) Orsi, 1904: 86, fig. 42. Two more finger rings lack precise dating: Orsi, 1904: 73, fig. 9; 77, fig. 22. 15A) Panvini, 1997: 501, fig. 20. 15B) Panvini and Pappalardo, 2005. Other rings might go back to the early LBA: Ribera (Agrigento), contrada Anguilla, tholos tomb 6, two finger rings (Panvini Di Stefano, 1986: 114); Milena (Caltanissetta), Monte Campanella, a wire ring and a band ring (Militello, 1992: 17).

List 3, Figure 3: LBA, late phase. 1) Venturino Gambari and Luzzi, 1999: 122, n. 28, figs. 103, 21. 2) Salzani, 1978: 119. 3) Bianchin Citton, 2003: 28, fig. 4. 4A) Salzani, 1990: 16, figs. 16, 3, 5; 4, 6, 7, 9. 4B) Salzani, 2003: 44, fig. 4, A and B. 5) Bettelli, 1997: 734, fig. 432, a and b. 6) Allumiere (Roma). A spiral wire from a burial urn (excavations by R. Peroni). 7) Müller-Karpe 1959: 103, tab. 12, 7; Gierow, 1966: 360-361. 8) Ugas, 1993: 30, fig. a, 25.9) Lo Schiavo and Usai, 1995: 174, fig. 19, 2-4; Lo Schiavo et al., 2004. 10) Bozzini et al., 2003; Guglielmino, 2003; Pagliara, 2003; Butalag et al., 2004; Pagliara and Guglielmino, 2005). 11) Pacciarelli, 2001: 192 ss., figs. 111, B and 114, 112 ) Bernabò Brea and Cavalier, 1960: 117-119, tav. XLI, 3). 13A) Orsi, 1899: tab. VIII, 15; Peroni, 1956: fig. 9, 62.
13B) Orsi, 1912: tab. VI, 23; Peroni, 1956: fig. 9, 142 S.O. 14) Orsi, 1912: col. 373, tab. XVII, 1.

\section{Acknowledgements}

This contribution is part of a long standing project with several participants coordinated by P. Piana Agostinetti (Piana Agostinetti et al., 1995); to her I owe many stimulating discussions and many thanks. We are grateful to R. Peroni, who brought to our attention a still unpublished spiral (List 3, n. 6). Many thanks to $G$. Montali for his unfailing friendly help with the illustrations.

\section{References}

Artioli, G., Bietti Sestieri, A.M., Cardarelli, A., de Marinis, R.C. and Giardino, C., 2005. Archeometallugia dell'Italia Protostorica. Progetto di ricerca dell'Istituto Italiano di Preistoria e Protostoria, at http://win.iipp.it/progetti1/archeometallurgia (13.06.2005).

Aspes, A., 1987. Franzine Nuove di Villabartolomea, in Prima della Storia. Inediti di 10 anni di ricerche a Verona. Verona: Museo Civico di Storia Naturale di Verona, 99-102.

Aspes, A. and Salzani, L., 1997. Gli oggetti ornamentali nella regione Veneta nella preistoria, in L. Endrizzi, F. Marzatico (eds.), Ori delle Alpi. Trento: Provincia autonoma di Trento, Servizio Beni Culturali, 538-541; 552, nn. 28-29.

Atzeni, C., Ciccotti, A., Massida, L. and Sanna, U., 2003. Prenuragic copper, arsenic, silver and gold, in Archaeometallurgy in Europe. International Conference, 24-26 September 2003, Milan, Italy: proceedings, vol. 2. Milano, Associazione Italiana di Metallurgia, 97-106.

Atzeni, E., 1998. La tomba ipogeico-megalitica di Bingia 'e Monti, in F. Nicolis, E. Mottes (eds.), Simbolo ed enigma. Trento, Provincia autonoma di Trento, Servizio Beni Culturali, 254-260.

Bergonzi, G. forthcoming, L'argento più antico: metallurgia dell'argento tra la Sardegna e la penisola italiana, Atti della XLIV Riunione Scientifica dell'Istituto Italiano di Preistoria e Protostoria.

Bermond Montanari, G., 1990. La lamina aurea di Redù, in Nonantola. Antiquarium: tracce del tempo. Nonantola: Comune di Nonantola, 69.

Bernabò Brea, L. and Cavalier, M., 1960. Meligunis Lipara I. Palermo: Flaccovio.

Bertone, A., Caranzano, S. and Rossi, P., 2004. Dalla pietra ai metalli, in A. Bertone, F. Fozzati (eds.), La civiltà di Viverone. Biella: Eventi e progetti, 53-69.

ArcheoSciences, revue d'archéométrie, 33, 2009, p. 91-97 
Bettelli, M., 1997. Elementi di culto nelle terramare, in M. Bernabò Brea, M. Cremaschi, A. Cardarelli (eds.), Le Terramare. Milano, Electa, 720-741.

Bianchin Citton, E., 2003. Montagnana - Borgo San Zeno (PD): l'abitato e le sue necropoli, in L. Malnati, M. Gamba (eds.), I Veneti dai bei cavalli. Treviso: Canova, 28-29.

Bietti Sestieri, A.M., 1973. The metal industry of continental Italy, 13th-11th century and its Aegean connections. Proceedings of the Prehistoric Society 39: 383-424.

Bozzini, B., Giovannelli, G., Pagliara, C., Guglielmino, R. and Maggiulli, G., 2003. Ceremonial Gold Artefacts of the Late Bronze Age from the Deposition Site of Roca: a Metallurgical Investigation, in Archaeometallurgy in Europe. International Conference, 24-26 September 2003, Milan, Italy: proceedings, vol. 1. Milano, Associazione Italiana di Metallurgia, 267-276.

Butalag, K., Demortier, G., Quarta, G., Muscogiuri, D., Pagliara, C., Maggiulli, G. and Calcagnile, L., 2004. Checking the homogeneity of gold artefacts of the final bronze age found in Roca Vecchia, Italy by Proton Induced X-Ray Emission, in Program and Book of abstracts: 8th European Conference on Accelerators in Applied Research and Technology (= ECAART). Paris: 116.

Caunet, B., 1999. L'or dans l'Antiquité, De la mine à l'objet, Aquitania, Suppl. 9.

Cristofani, M. and Martelli, M., 1983. L'oro degli Etruschi. Novara: Istituto Geografico De Agostini.

DE MARINIS, R.C., 2000. Il museo civico Giovanni Rambotti: una introduzione alla preistoria del lago di Garda. Desenzano del Garda: Comune di Desenzano del Garda.

Giardino, C., 1998. I metalli nel mondo antico. Roma and Bari, Laterza.

Giardino, C. and Merkouri, C., 2008. Greece and Southern Italy: the precious connection, in S.A. Paipetis, C. Giannopoulou (eds.), Cultural cross fertilisation of Southern Italy and Western Greece through history. Patras: N.E.O. Patron-Athinon, 108128.

Gierow, P.G., 1966. The Iron Age culture of Latium 1. Acta Instituti Romani Regni Sueciae. Series prima in $4^{\circ}$. Lund, C.W.K. Gleerup.

Guerreschi, G., Limido, C. and Catalani, P., 1985. L'insediamento preistorico dell'Isolone del Mincio (Volta Mantovana): scavi Mirabella, Rittatore, Zorzi, 1955-56. Cavriana, Museo archeologico dell'Alto Mantovano.

Guglielmino, R., 2003. Il sito di Roca Vecchia: testimomianze di contatti con l'Egeo, in F. Lenzi (ed.), L'archeologia dell'Adriatico dalla Preistoria al Medioevo. Firenze, All' insegna del giglio, 91-119.

Hartmann, A., 1970. Prähistorische Goldfunde aus Europa I. Studien zu den Anfängen der Metallurgie 3. Berlin, Mann.
Hartmann, A., 1982. Prähistorische Goldfunde aus Europa II. Studien zu den Anfängen der Metallurgie 5. Berlin, Mann.

von Hase, F.W., 1975. Zur Problematik der frühesten Goldfunde in Mittelitalien. Hamburger Beiträge zur Archäologie 5: 99-182.

Junghans, S., Sangmeister, E. and Schröder, M., 1960. Metallanalysen kupferzeitlicher und frühbronzezeitlicher Bodenfunde aus Europa, Studien zu den Anfängen der Metallurgie 1. Berlin, Mann.

Junghans, S., Sangmeister, E. and Schröder, M., 1968. Kupfer und Bronze in der frühen Metallzeit Europas. Studien zu den Anfängen der Metallurgie 2. Berlin, Mann.

LeHrberger, G., 1995. The gold deposits of Europe: An overview of the possible metal sources for prehistoric gold objects, in G. Morteani, J.P. Northover (eds.), Prehistoric Gold in Europe. Mines, Metallurgy and Manufacture. Dordrecht, Boston, London, Kluwer Academic Publishers, 115-144.

Lo Schiavo, F. and UsaI, L., 1995. Testimonianze culturali di età nuragica: la grotta Pirosu in località su Benatzu di Santadi, in V. Santoni (ed.), Carbonia ed il Sulcis. Archeologia e territorio. Oristano, Editrice S’Alvure, 147-186.

Lo Schiavo F., Antona A., Bafico S., Campus F., Cossu T., Fonzo O., Forci A., Garibaldi P., Isetti E., Lanza S., Leonello V., Perra M., Puddu M. G., Relli R., Rossi G., Sanges M., Usai A. and Usai L. 2004. Articolazioni cronologiche e differenziazioni locali . La metallurgia, in D. Cocchi Genick (ed.), L'età del Bronzo recente in Italia, Viareggio (Lucca), Mauro Baroni, 357-382.

MarazzI, M., 1999. I Micenei a Vivara o i Micenei di Vivara? Un bilancio delle ricerche a vent'anni dall'inizio degli scavi, in V. La Rosa, D. Palermo, L. Vagnetti (eds.), Epi Ponton Plazomenoi. Roma, Scuola archeologica italiana di Atene, 415-421.

Militello, P., 1992. Due anelli d'oro dalle pendici sud-ovest di Monte Campanella. Quaderni dell'Istituto di Archeologia della Facoltà di Lettere e Filosofia dell'Università di Messina 6: 17-21.

Müller-Karpe, H., 1959. Vom Anfang Roms. Heidelberg, Kerle.

Mutti, A., Provenzano, N., Rossi, M.G. and Rottoli, M., 1988. La terramara di Castione dei Marchesi. Studi e Documenti di Archeologia 5. Bologna, Nuova Alfa Editoriale.

Neugebauer-Maresch, C. and Neugebauer, J.W., 1988/1989. Goldobjekte aus den Frühbronzezeitnekropolen Franzenhausen I und II und Gemeinlebarn F. Mitteilungen der Anthropologischen Gesellshaft in Wien 118/119: 101-134.

OrsI, P., 1899. Pantalica e Cassibile. Monumenti Antichi dei Lincei 9: 33-149.

OrsI, P., 1904. Siculi e Greci a Caltagirone. Notizie degli Scavi 5: 65-98.

OrsI, P., 1912. La necropoli sicula di Pantalica e la necropoli sicula di Monte Dessueri. Monumenti Antichi dei Lincei 21: 301-408. 
Pacciarelli, M., 2001. Dal villaggio alla città. Firenze, All'Insegna del Giglio.

Pagliara, C., 2003. Il sito di Roca Vecchia nell'età del Bronzo, in F. Lenzi (ed.), L'archeologia dell'Adriatico dalla Preistoria al Medioevo. Firenze, All'Insegna del Giglio, 74-90.

Pagliara, C. and Guglielmino, R., 2005. Roca: dalle curiosità antiquarie allo scavo stratigrafico, in S. Settis, C. Parra (eds.), Magna Graecia. Archeologia di un sapere. Milano, Electa, 298321.

Panvini Di Stefano, R., 1986. La necropoli preistorica di contrada Anguilla di Ribera, in M. Marazzi, S. Tusa, L. Vagnetti (eds.), Traffici micenei nel Mediterraneo. Taranto, Istituto per la storia e l'archeologia della Magna Grecia, 113-122.

Panvini, R., 1997. Osservazioni sulle dinamiche formative socioculturali a Dessueri, in S. Tusa (ed.), Prima Sicilia. Alle origini della società siciliana 1. Palermo, Ediprint, 493-502.

Panvini, R. and Pappalardo, G., 2005. Due pugnaletti con manico d'avorio dalla necropoli protostorica di Dessueri, in L. Vagnetti, M. Bettelli, I. Damiani (eds.), L'avorio in Italia nell'età del bronzo. Roma, CNR - ICEVO, 105-110.

Perini, R. 1987. Scavi archeologici nella zona palafitticola di FiavéCarera II. Trento, Servizio Beni Culturali della Provincia Autonoma di Trento.

Peroni, R., 1956. Per una distinzione in fasi della necropoli del II periodo siculo a Pantalica. Bullettino di Paletnologia Italiana 65: 387-432.

Peroni, R., 1963. Ripostigli delle età dei metalli 3. Ripostigli dell'appennino umbro-marchigiano. I, 6 - I, 8, Inventaria Archaeologica Italia fasc. 3. Firenze, Sansoni.

Piana Agostinetti, P., Bergonzi, G., Cattin, M., Del Soldato, M., Gambari, F.M. and Tizzoni, M., 1995. Gold in the Alps: A View from the South, in G. Morteani e J.P. Northover (eds.), Prehistoric Gold in Europe. Mines, Metallurgy and Manufacture.
Dordrecht, Boston, London, Kluwer Academic Publishers, 199-218.

Primas, M., 1995. Gold and silver during the 3rd Mill. cal. BC, in G. Morteani and J.P. Northover (eds.), Prehistoric Gold in Europe. Mines, Metallurgy and Manufacture, Dordrecht, Boston, London, Kluwer Academic Publishers, 77-93.

Primas, M., 1996. Velika Gruda I. Bonn, Habelt.

Procelli, E., Albanese Procelli, R.M. and Panvini, R. and Tusa, S., 2004. Sicilia. Le necropoli, in D. Cocchi Genick (ed.), L'età del Bronzo recente in Italia. Viareggio (Lucca), Mauro Baroni, 335-346.

SAlzani, L., 1978. La necropoli dell'età del Bronzo a Fontanella Mantovana. Preistoria Alpina 14: 115-162.

SALZANi, L., 1990. Necropoli dell'età del Bronzo Finale alle Narde di Fratta Polesine. Prima nota. Padusa 25: 5-42.

SAlZANI, L., 1998/1999. Sepolture dell'antica età del Bronzo da Valserà di Gazzo Veronese (VR). Padusa 34/35: 63-75.

SAlZaNI, L., 2003. Recenti rinvenimenti nel Polesine. Fratta Polesine. Il ripostiglio n. 4 e altri reperti da Frattesina. Quaderni di Archeologia del Veneto 19: 40-45.

UGas, G., 1993. La metallurgia del piombo, dell'argento e dell'oro nella Sardegna prenuragica e nuragica, in T.K. Kirova (ed.), L'uomo e le miniere in Sardegna. Cagliari, Edizioni della Torre.

Venturino Gambari, M. and Luzzi, M., 1999. Catalogo, in M. Venturino Gambari (ed.), In riva al fiume Eridano. Una necropoli dell'età del Bronzo finale a Morano sul Po. Torino, Edizioni dell'Orso, 103-141.

VozA, G., 1973. Thapsos, in Archeologia della Sicilia Sud-Orientale. Napoli, Centre Jean Berard, 30-52.

Voza, G., 1997. Schede del Catalogo in S. Tusa (ed.), Prima Sicilia. Alle origini della società siciliana 1, Palermo, Ediprint, 166-175. 
